\title{
Macrophyte development in unimpacted lowland rivers in Poland
}

\author{
Krzysztof Szoszkiewicz • Szymon Jusik • \\ Agnieszka E. Lawniczak • Tomasz Zgola
}

Published online: 18 September 2010

(C) The Author(s) 2010. This article is published with open access at Springerlink.com

\begin{abstract}
Freshwater classification according to the Water Framework Directive (WFD) is based on estimation of the deviation between biological elements found on river stretch in comparison with communities detected in the same river type under reference conditions (undisturbed and near-natural habitats). We present analyses to describe macrophyte development in pristine lowland rivers and to reveal the variation among various stream types. The study is based on a country-wide survey of Poland with a dataset of 642 sites on 367 water courses. Surveyed rivers covered the whole lowland area of Poland. Field surveys were conducted using the Polish macrophyte approach, which enabled calculation of several macrophyte metrics. Firstly, a numerical index MIR
\end{abstract}

Guest editors: A. Pieterse, S. Hellsten, J. Newman, J. Caffrey, F. Ecke, T. Ferreira, B. Gopal, J. Haury, G. Janauer,

T. Kairesalo, A. Kanninen, K. Karttunen, J. Sarvala, K. Szoszkiewicz, H. Toivonen, L. Triest, P. Uotila, N. Willby / Aquatic Invasions and Relation to Environmental Changes: Proceedings of the 12th International Symposium on Aquatic Weeds, European Weed Research Society

K. Szoszkiewicz $(\bowtie) \cdot$ S. Jusik · A. E. Lawniczak ·

T. Zgola

Department of Ecology and Environmental Protection, Poznan University of Life Sciences, ul. Piatkowska 94C, 60-649 Poznan, Poland e-mail: kszoszk@up.poznan.pl
(Macrophyte Index for Rivers) was computed, which reflects river degradation, especially eutrophication. Furthermore, five diversity metrics were calculated. Each survey, in addition to macrophyte assessment, was supplemented by a complex suite of environmental records. Reference conditions were defined using four criteria: (1) catchment land use, (2) hydromorphological features, (3) water quality and (4) biological assessment. The selected reference lowland rivers included 40 sites. To classify plant data, two-way indicator species analysis Twinspan was used. This resulted in distinguishing four endclusters which were heterogeneous according to plant composition: organic rivers and three types of siliceous rivers (small with sandy substrate, small with stony substrate and large rivers). The differentiation of environmental factors between river types was confirmed by a variance analysis (ANOVA). Furthermore, the environmental database was explored with principal component analysis (PCA). The PCA principal components were analysed against river types with the canonical correspondence analysis (CCA). Finally botanical differences between identified river types have been detected, using botanical metrics the share of different macrophyte groups and relationships with particular species were defined.

Keywords Macrophytes - Rivers - Reference conditions - River types - Biological indicators . Water Framework Directive 


\section{Introduction}

The reaction of aquatic plants to changing environmental conditions is often used to detect river degradation. The macrophyte-based methods focus mainly on identifying eutrophication (Haury, 1996; Holmes et al., 1999; Schneider et al., 2000; Haury et al., 2006) and acidification (Tremp \& Kohler, 1995). However, macrophyte methods also exist to assess river degradation in a more holistic or integrative way (Ferreira et al., 2002; Passauer et al., 2002; Van De Weyer, 2003; Schaumburg et al., 2004). The importance of macrophytes in river biological assessment is formally recognised under the Water Framework Directive (European Commission, 2000). This group of organisms is an obligatory element in the monitoring of ecological status of surface water quality. For the purpose of river monitoring, several systems based on aquatic plants have been developed and some of them have been integrated into national monitoring programmes, e.g. in Denmark (Svendsen \& Rebsdorf, 1994), Germany (Schaumburg et al., 2004), France (Haury, 1996; Haury et al., 2006) and Poland (Szoszkiewicz, 2004).

Freshwater classification according to WFD is based on estimation of biological indicators deviation met on river stretch in comparison with communities detected under reference conditions (undisturbed and near-natural habitats). Therefore, studies on reference conditions are of primary importance for biological monitoring and should be completed for each existing river type.

Existing knowledge about macrophytes in unimpacted European streams and rivers is still limited, considering its importance. On this subject, BaattrupPedersen et al. (2006) outlined reference macrophyte communities in the geographically wide European context. More local (limited to Germany) although more comprehensive studies on river plants were conducted in Germany (Meilinger et al., 2005). A relatively large matrix of lowland data was compiled from different sources and analysed by BaattrupPedersen et al. (2008), which resulted in identification of several different macrophyte assemblages.

Our studies focus on the response of macrophytes in reference conditions. We expected to find correspondence with other European surveys, especially German (Meilinger et al., 2005) although further information was expected to be gathered. Though our analyses are based on a large number of sites, the collected data still represents a high degree of homogeneity, since macrophyte and habitat surveys were all collected in the uniform pattern by a group of experienced and well-calibrated surveyors. The interpersonal source of error, which can be very influential in the assessment of aquatic plants (Staniszewski et al., 2006), was considerably low in our studies. Moreover, conducted surveys covered the whole lowland part of Poland, which delivers a wide range of ecological habitats and they are consistent with the majority of existing river types across central and northern part of Europe (Meilinger et al., 2005; Baattrup-Pedersen et al., 2006, 2008). We also expect that by our efforts in finding and surveying every potential reference site, including the river systems regarded as European best quality sites and unique sites (Raven et al., 2008), we can deliver significant information about reference conditions on a European scale.

Our analyses are dedicated to describe macrophyte development in pristine lowland rivers and to reveal their variation among various stream types. Studies were focused on revealing existing patterns at the level of species and ecological groups of species. Moreover, studies included analyses of variability of several indices calculated on the base of botanical data.

\section{Materials and methods}

Site selection

The study is based on a country-wide survey of Poland with a dataset of 642 sites placed on 367 water courses (Fig. 1). The completed database was the result of several projects which were run between 2003 and 2008 and the field surveys were undertaken personally (or at least assisted) by authors of this article.

Surveyed rivers covered the whole lowland area of Poland (Fig. 1) and we accomplished a lot by reaching every potential reference site. During the surveys, all existing lowland river types were investigated (Blachuta et al., 2005). Regarding geological criteria, substrate type and catchment area, eight lowland river types were identified in Poland and six of them were included in analyses. Two river types were excluded due to lack of reference sites in Poland (Estuary under influence of salty waters) and absence 


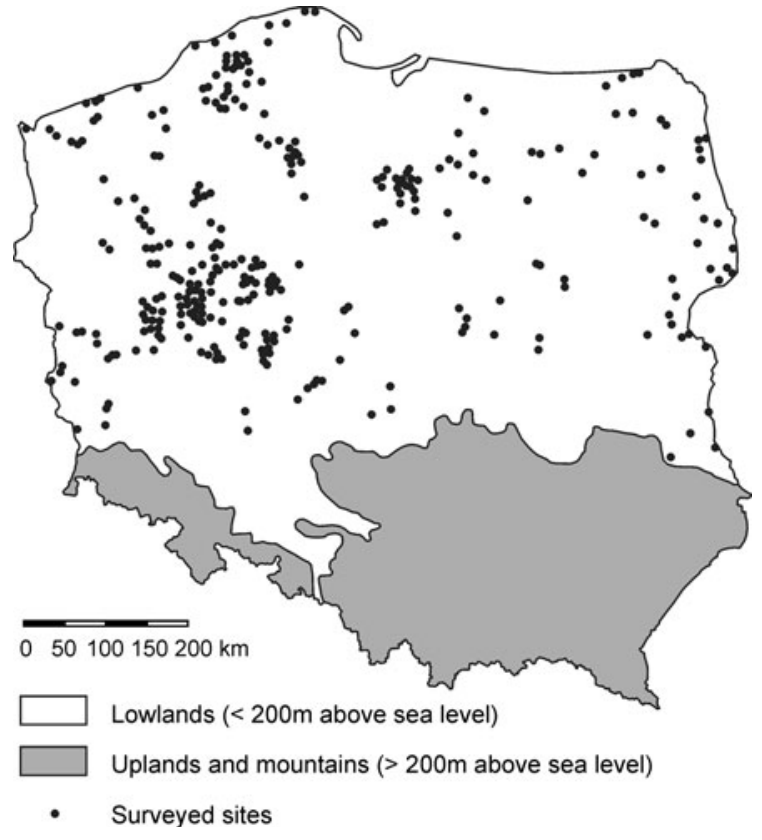

Fig. 1 Distribution of the survey sites

of macrophytes in reference conditions (loess-clay substrate). Among the analysed types, organic rivers and two siliceous forms of watercourses were included, which were characterised by sandy substrates (fine material) and stony substrates (typically, in lowland conditions dominated by pebble and gravel material with some cobble components). Each geological type was represented by different size categories: small (catchment area under $100 \mathrm{~km}^{2}$ ), medium/large (catchment area over $100 \mathrm{~km}^{2}$ ).

\section{Macrophyte surveys}

Macrophyte surveys were undertaken during the summer seasons - between July and early September. Field surveys were conducted using the Macrophyte Method for Rivers (Szoszkiewicz et al., 2010). This method which is currently the official monitoring approach for rivers in Poland is consistent with the majority of European methods, mainly MTR (Holmes et al., 1999), IBMR (Haury et al., 2006) and the EU-STAR project methodology (Dawson, 2002). Macrophyte surveys included identification of all submerged, free-floating, amphibious and emergent monocotyledonous and dicotyledonous plant species, as well as filamentous algae, liverworts, mosses and pteridophytes. The assessment included macrophytes attached or rooted in parts of a river bank that are likely to be submerged for more than $85 \%$ of a year length. The macrophyte survey reach was $100 \mathrm{~m}$ long. The presence of each species was recorded with their percentage cover using following nine-point scale: $<0.1 \%, 0.1-1 \%, 1-2.5 \%, 2.5-5 \%, 5-10 \%$, $10-25 \%, 25-50 \%, 50-75 \%,>75 \%$. In wadeable survey sites, a glass-bottom bucket was used to aid observations. For non-wadeable parts of the largest rivers, a grapnel was used to retrieve macrophyte species from a channel.

Basing on gathered field records, several macrophyte metrics were calculated (Table 1). First, a numerical index MIR (Macrophyte Index for Rivers) was computed. It reflects river degradation, especially eutrophication and ranges from 10 (most degraded rivers) to 100 (highest quality). Furthermore, five diversity metrics were calculated, these were: species richness $(N)$, Shannon diversity (Shannon \& Weaver, 1949), Simpson diversity (Simpson, 1949), domination (McNaughton, 1967) and evenness (Pielou, 1966).

Collected records enabled estimation of a total cover of vegetation for each surveyed section. Moreover, the share of various growth forms of plants was analysed by distinguishing six categories: helophytes (emergent plants), nympheides (floating leavesrooted), pleustophytes (floating leaves-unrooted), elodeides (submerged plants), bryophytes (mosses and liverworts) and algae (algae developing filamentous forms).

\section{Site characteristics}

Each survey, in addition to macrophyte assessment, was supplemented by a complex suite of environmental records (Table 2). They included: catchment land use, hydromorphological data and hydrochemical measurements.

The data on catchment area and land use of watersheds were derived from the GIS database built for CORINE (Coordination of Information on the Environment) Land Cover. Land use is presented as a vector layer. The precision of the layer is designated to $1: 100,000$ scale maps. The smallest distinguished area is 25 ha. The CORINE database includes 44 categories of different land use types. Many of these categories were absent in the catchment areas analysed, often due to lack of heavily modified areas 
Table 1 Macrophyte metrics calculated for river sites

$p s_{i}$ Abundance of species $i$ in a site in 9-point scale, $l_{i}$ indicative value of species $i, w_{i}$ weight (ecological tolerance) of species $i, p_{i}$ relative abundance of species $i$ in a site

Table 2 Variables recorded in the environmental database

\begin{tabular}{llll}
\hline Name of index & Symbol & Formula & Source \\
\hline $\begin{array}{l}\text { Marophyte index } \\
\text { for rivers }\end{array}$ & MIR & MIR $=\frac{\sum_{i=1}^{N} l_{i} \cdot w_{i} \cdot p s_{i}}{\sum_{i=1}^{N} w_{i} \cdot p s_{i}} \cdot 10$ & Szoszkiewicz et al. (2010) \\
$\begin{array}{l}\text { Species richness } \\
\text { Shannon diversity }\end{array}$ & $N$ & Number of species & - \\
Simpson diversity & $D$ & $H^{\prime}=-\sum_{i=1}^{N}\left(p_{i} \cdot \log _{2} p_{i}\right)$ & Shannon \& Weaver (1949) \\
Domination & $C$ & $D=1-\sum_{i=1}^{N} p_{i}^{2}$ & Simpson (1949) \\
Evenness & $J$ & $C=\sum_{i=1}^{N}\left(\frac{p_{i}}{\sum_{i=1}^{N} p_{i}}\right)^{2}$ & McNaughton (1967) \\
\hline
\end{tabular}

\begin{tabular}{|c|c|c|c|}
\hline Parameter & Units & Transformation & Shortcode \\
\hline \multicolumn{4}{|l|}{ Catchment and land use } \\
\hline 1. Catchment area & $\mathrm{km}^{2}$ & $\ln (x+1)$ & Catchment \\
\hline 2. Land use_-arable land & $\%$ & - & Arable $\%$ \\
\hline 3. Land use-grassland & $\%$ & - & Grass $\%$ \\
\hline 4. Land use-forest and seminatural area & $\%$ & $\ln (x+1)$ & Forest $\%$ \\
\hline $\begin{array}{l}\text { 5. Land use-wetlands and freshwater } \\
\text { ecosystems }\end{array}$ & $\%$ & $\sqrt{x}$ & Wetland\% \\
\hline \multicolumn{4}{|l|}{ Hydromorphological metrics } \\
\hline 6. Habitat Quality Assessment & $\begin{array}{l}\text { Quantitive } \\
\text { (0-100) }\end{array}$ & - & HQA \\
\hline 7. Habitat Modification Score & $\begin{array}{l}\text { Quantitive } \\
\text { (0-100) }\end{array}$ & $\ln (x+1)$ & HMS \\
\hline \multicolumn{4}{|l|}{ Hydrochemistry } \\
\hline 8. $\mathrm{pH}$ & $\mathrm{pH}$ & - & $\mathrm{pH}$ \\
\hline 9. Conductivity & $\mu \mathrm{S} / \mathrm{cm}$ & $\ln (x+1)$ & Cond \\
\hline 10. Alkalinity & $\mathrm{mg} / \mathrm{dm}^{3}$ & $\sqrt{x}$ & Alkal \\
\hline 11. Ammonium & $\mathrm{mg} / \mathrm{dm}^{3}$ & $\ln (x+1)$ & Amm \\
\hline 12. Nitrate & $\mathrm{mg} / \mathrm{dm}^{3}$ & $\ln (x+1)$ & Nitrate \\
\hline 13. Ortho-phosphate & $\mu \mathrm{g} / \mathrm{dm}^{3}$ & $\sqrt{x}$ & Ortho_P \\
\hline 14. Total phosphate & $\mu \mathrm{g} / \mathrm{dm}^{3}$ & $\sqrt{x}$ & Total_P \\
\hline
\end{tabular}

in the reference conditions. Finally, four different groups of land use were distinguished: arable lands, grasslands, forests and semi-natural areas, wetlands and freshwater ecosystems.

The hydromorphological evaluation was conducted at each site according to River Habitat Survey (RHS) method (Environment Agency, 2003). RHS gathers data over a 500-m stretch of a river. The RHS survey is performed in 10 profiles (spot-checks), which are distributed at $50 \mathrm{~m}$ intervals. The macrophyte survey section was located inside each RHS site, always between 6th and 8th spot-check, two numerical metrics based on RHS protocol were produced (Raven et al., 1998):

- Habitat Modification Score (HMS) based on the extent and type of artificial features and modifications,

- Habitat Quality Assessment (HQA) based on the extent and variety of natural features recorded.

High values of HQA indicate an extensive presence of a number of natural river features and high 
landscape diversity along the river, while low values show lack of natural features. Low HMS score indicates limited artificial modifications of watercourses, whereas higher values of the index indicate considerably high habitat modification.

Water samples for the chemical analysis were collected usually during the same visit when botanical and hydromorphological surveys were undertaken. Samples were never collected during the rainy weather, and in such situations, the additional visit to collect the water sample was organised. Surface water samples were taken mid-stream below the surface. All samples were filtered using Sartorius Cellulose filters with nominal pore size $0.45 \mu \mathrm{m}$, except those for the determination of total P. Water samples were cooled and analysed in laboratory within a 12-h period. Water temperature, $\mathrm{pH}$ and electrical conductivity were measured by digital potentiometers (Elmetron CP-401, CC-551). Alkalinity was measured with sulphuric acid to an end point of $\mathrm{pH} 4.5$ using $\mathrm{pH}$ analyser (Elmetron CPI-551). Concentrations of total phosphorus (acid persulphate digestion method), orthophosphorous (amino acid method), nitrate (cadmium reduction method) and ammonium (Nessler's method) were determined using a spectrophotometer HACH DR/2400.

Data analysis

To classify plant data, two-way indicator species analysis Twinspan (Hill, 1979) was used. This method is a multivariate ordination technique for classifying species and samples. The output result of the analysis is a two-way ordered table of species occurrence based on a multi-level, two-way partitioning of the correspondence analysis scores. The analyses were undertaken with PISCES Community Analysis Package 2.0 Twinspan. The major Twinspan end-clusters were related with existing river typology for Poland and were proposed as macrophyte river types.

Analyses of environmental databases were started by testing the distribution of environmental variables, using the W-value according to Shapiro-Wilk criteria (StatSoft, Inc., 2008). To normalise distribution, most of the variables were transformed, mainly through square root or logarithmic conversion (Tables 2, 3).

To test differentiation of environmental factors between river types, an analysis of variance (ANOVA) was performed (StatSoft, Inc., 2008). Moreover, a factor analysis (principal component analysis-PCA) was used to uncover the structure of environmental matrices and revealed directions of ecological variability were used in further analysis. Principal components revealed within the PCA analysis were used with canonical correspondence analysis (CCA) as environmental variables against identified river types (Ter Braak \& Prentice, 1988).

To identify any botanical distinctness of distinguished river types, the significance of differences of macrophyte metrics were tested. Analyses included: MIR, five diversity metrics and presence of six growth forms. The relationship between individual macrophyte species and identified river types was performed using CCA.
Table 3 River typology database supported by abiotic criteria, which was prepared according to requirements of the WFD in Poland (Blachuta et al., 2005)

a Sites without macrophytes

\begin{tabular}{lllrr}
\hline $\begin{array}{l}\text { Symbol of } \\
\text { stream type }\end{array}$ & Geologic criteria & Size criteria & \multicolumn{2}{c}{ Number of sites } \\
\cline { 3 - 5 } & & & $\begin{array}{l}\text { All } \\
\text { sites }\end{array}$ & \multicolumn{2}{c}{$\begin{array}{l}\text { Reference } \\
\text { sites }\end{array}$} \\
\hline 16 & Loess-clay & Small & 12 & $2^{\mathrm{a}}$ \\
17 & Siliceous-sandy & Small & 266 & 10 \\
18 & Siliceous-stony & Small & 55 & 7 \\
19 & Siliceous-sandy & Medium and large & 238 & 7 \\
20 & Siliceous-stony & Medium and large & 39 & 8 \\
23 & Organic & Small & 38 & 3 \\
22 & Estuary under influence & Small, medium and large & 11 & 0 \\
24 & of salty waters & & 36 & 5 \\
& Organic & Medium and large & 695 & 42 \\
\hline
\end{tabular}




\section{Results}

Selection of reference sites

The reference sites were selected from the whole database using four criteria: (1) catchment land use, (2) hydromorphological features, (3) water quality and (4) biological assessment. Land use was analysed in the catchment area stretching from a source to a survey site. Land use reference conditions were considered regarding following criteria: more than $60 \%$ of catchment area covered by forest, wetlands or extensive grasslands, less than $25 \%$ of catchment area covered by arable fields and less than $1 \%$ catchment area covered by urban area. A good hydromorphological status was characterised by significant heterogeneity of channel geomorphological structure and lack of human alteration of river systems $(\mathrm{HMS}=0)$. Geomorphologic units included bedrock pools, runs, cascades (HQA $\geq 48$ ). Concerning water quality, low nutrient concentration was required, although in case of some river types (large or/and organic) the desired criteria were not onerous: reactive phosphorus $<0.3 \mathrm{mg} \mathrm{PO}_{4}{ }^{3-} / \mathrm{dm}^{3}$, total phosphorus $<0.3 \mathrm{mg} \mathrm{P} / \mathrm{dm}^{3}$, nitrate $<1.0 \mathrm{mg} \mathrm{N}-\mathrm{NO}_{3}{ }^{-} / \mathrm{dm}^{3}$, ammonium $<0.4 \mathrm{mg}$ $\mathrm{N}-\mathrm{NH}_{4}{ }^{+} / \mathrm{dm}^{3}$, conductivity $<0.6 \mathrm{mS} / \mathrm{cm}$, thermal conditions similar to natural and lack of anthropogenic acidification and salinity. Forty water courses were selected which fitted the criteria. For the number of selected sites, existing biological data have been utilised, as saprobic index, results of benthic macroinvertebrate assessment, chlorophyll $a$ level end others. These data were gathered form the national monitoring reports and several local scientific studies.

Identification of existing river types

TWINSPAN analysis based on occurrence of freshwater plants in 40 reference sites resulted in a clear separation of analysed sites (Fig. 2). The first dichotomy resulted in an evident split (eigenvalues $=0.56$ ), which separated 15 small siliceous streams from other rivers. This subset was identified by Twinspan analysis by the presence of mosses (Brachythecium rivulare and Cratoneuron filicinum) and Veronica beccabunga. The next division separated this subset into two clusters: one with sandy substrates and the second with stony substrates consisting of large amount of gravel supplemented by pebbles and cobbles. Based on this analysis, two macrophyte river types were revealed: small siliceous streams with sandy substrate (abbreviation small sandy) and small siliceous streams with stony substrate (abbreviation small stony).

The other group separated in the first split was more diverse. The second split of this group separated a clear group of 10 streams characterised by the presence of Carex rostrata and Phragmites australis with Fontinalis antipyretica being absent. The cluster includes only organic rivers according to abiotic criteria (Blachuta et al., 2005). This cluster combined various size categories of rivers (from small to large). All these gave the background to identify the third macrophyte river type-organic rivers (abbreviation organic).
Fig. 2 Dendrogram representing the TWINSPAN classification of recorded vegetation

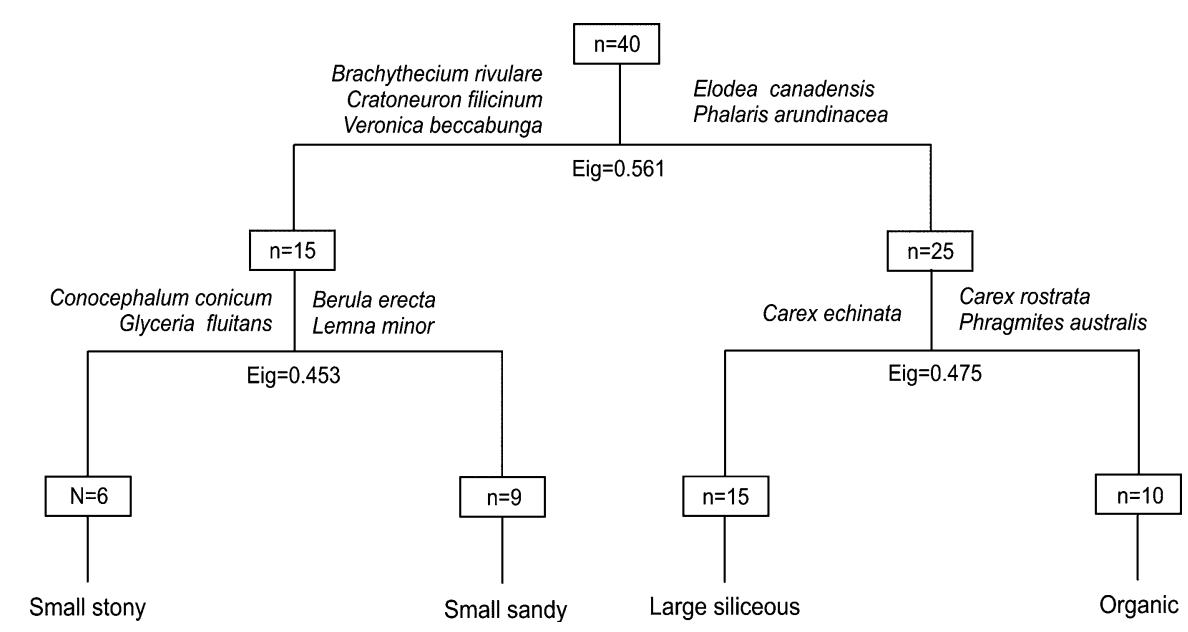


The last identified river type was a large group of rivers separated from organic rivers in the second split of Twinspan. The group consists of siliceous rivers with sandy or stony substrates. This group includes only large rivers (catchment bigger than $100 \mathrm{~km}^{2}$ ). The abbreviation for this group is large siliceous.

Generally, the analysis of vegetation heterogeneity undertaken by the TWINSPAN resulted in distinguishing four evident end-clusters which differ in plant composition. They were identified as four macrophyte-based types of lowland rivers. These are organic rivers and three types of siliceous rivers (small with sandy substrate, small with stony substrate and large rivers).

Habitat description of river types

Analysis of the environmental matrix did not fulfil normal distribution requirements. The hypothesis about the normal distribution failed after conducting the $W$ value test according to Shapiro-Wilk criteria. To normalise the distribution, most of the variables were transformed, mainly using square root or logarithmic conversion (Table 2).

To identify specific ecological elements of the four revealed river types, an analysis of variance (ANOVA) was performed (Table 4). The ANOVA

Table 4 Analysis of variance of environmental factors between river types

\begin{tabular}{lcc}
\hline Variable & $F$ distribution & $P$ value \\
\hline Catchment & 10.15 & $<0.001^{* * *}$ \\
Arable\% & 3.30 & $0.023^{*}$ \\
Grass\% & 3.57 & $0.024^{*}$ \\
Forest\% & 2.95 & $0.027^{*}$ \\
Wetland\% & 1.59 & 0.145 \\
HQA & 3.52 & $0.028^{*}$ \\
HMS & 1.23 & 0.360 \\
Alcal & 0.55 & 0.615 \\
Cond & 0.22 & 0.854 \\
pH & 6.82 & $0.001^{* *}$ \\
Ortho_P & 0.60 & 0.618 \\
Total_P & 0.12 & 0.990 \\
Nitrate & 1.59 & 0.218 \\
Ammonium & 1.51 & 0.259 \\
\hline
\end{tabular}

Full names of environmental variables are given in Table 3 df $=20 ; * P<0.05$; ** $P<0.01 ; * * * P<0.001$ results were significant for most of 14 environmental variables tested. Analysis showed that identified river types indicate significant differences according to the numerous environmental variables. The most significant differences were in the catchment area $(P<0.001)$.

Several elements indicating ecological uniqueness of identified river types were discovered as a result of the analysis. Catchment area was significantly different in comparison of small river types (both sandy and stony) with the other two river types (Fig. 3). A significant difference in the share of arable land and forests between watershed of organic rivers and large siliceous rivers was found (Fig. 3). The smallest share of grassland was found in the watershed of small stony rivers (Fig. 3). Only one of the two calculated hydromorphological indices appeared as significantly different between identified river types. HQA confirmed the differentiation between organic rivers and small sandy streams (Fig. 3). Large differences between water $\mathrm{pH}$ were detected. The $\mathrm{pH}$ of small stony streams was higher than in sandy and organic rivers. Moreover, $\mathrm{pH}$ of organic rivers was lower than in large siliceous rivers and small stony streams. The $\mathrm{pH}$ of small stony streams was higher than $\mathrm{pH}$ of small sandy rivers.

Principal component analysis has given simplified habitat description of the analysed matrix. It was found that the first three factors are responsible for $56.2 \%$ of the sample variance. Table 5 presents three principal components and their corresponding eigenvalues after varimax rotation. It can be seen that each of three eigenvalues are responsible for more than $10 \%$ of variance.

The first principal component was strongly associated with a catchment area $(r=0.75)$, therefore it can be defined as the gradient indicating size of the river and its hydrological dimension. This component was named as 'River size'. The second principal component extracted is strongly related with the land use practice. It is most strongly associated (negatively) with share of forest $(r=0.90)$ and the presence of arable land (positively) in a catchment $(r=0.89)$. This gradient indicated also some relationship with $\mathrm{pH}$. It was named as 'Deforestation' gradient. Finally, the third principal component extracted is strongly positively associated with phosphorus (soluble reactive and total). It also shows some relationship with ammonia concentration and 
Fig. 3 Variability of environmental parameters among the river types. The plot indicates mean value, \pm standard error and $\pm 1.96 *$ standard error. The six selected variables are those which indicated significant differences between river types. Full names of variables and their description are in Table 3
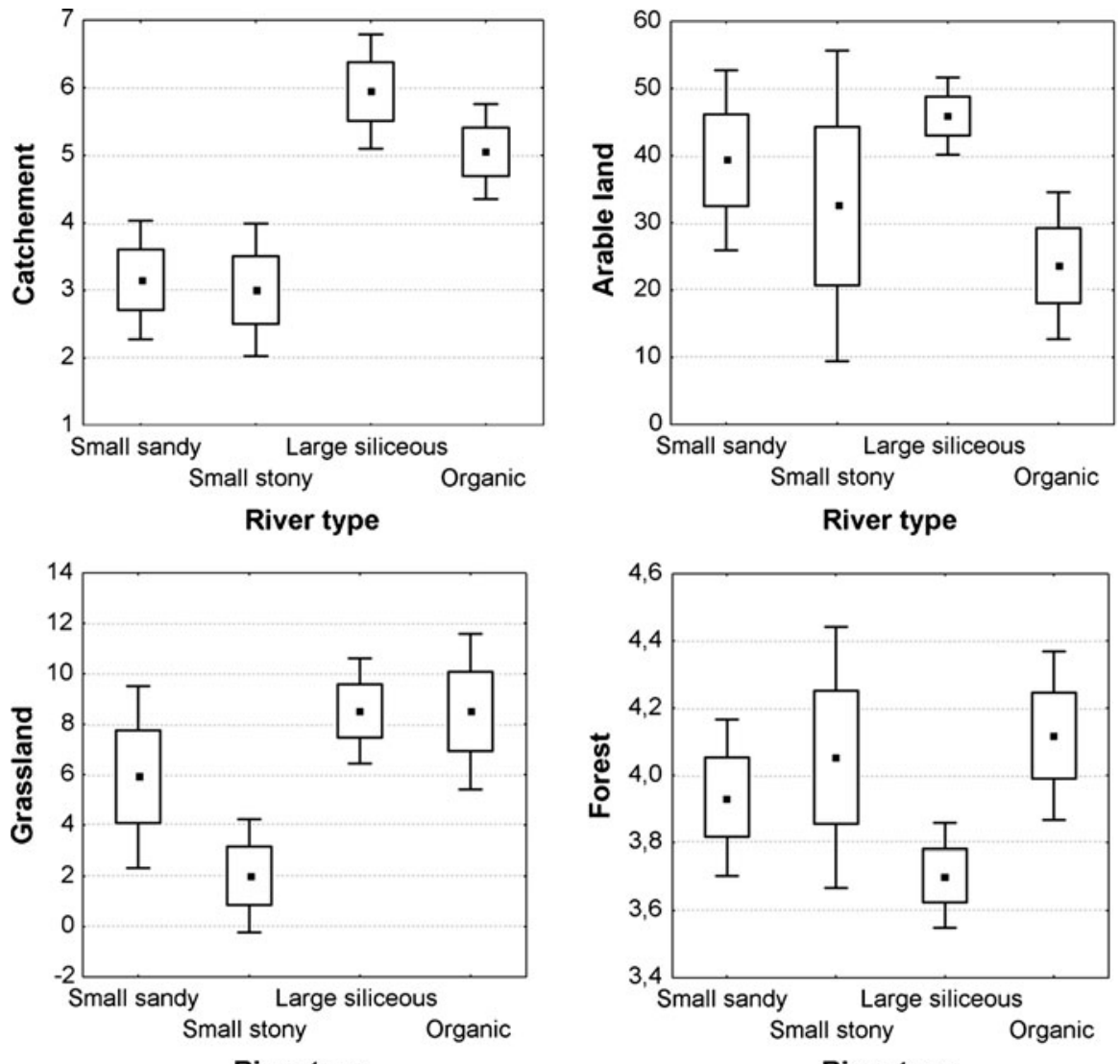

River type

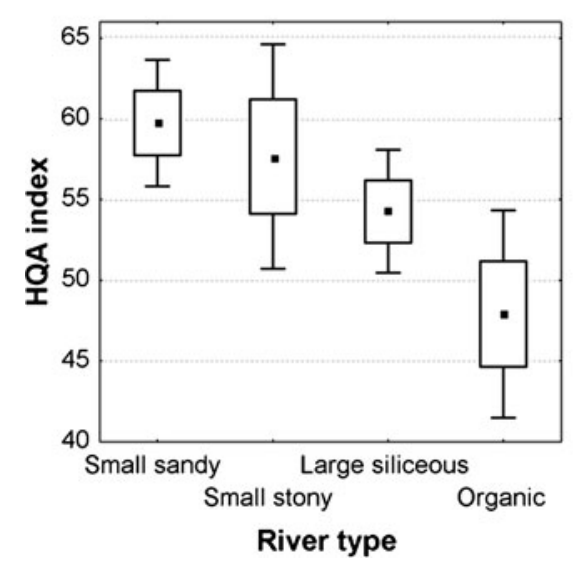

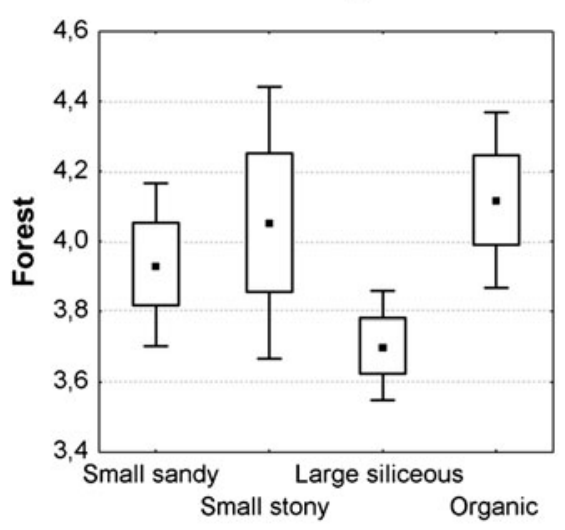

River type

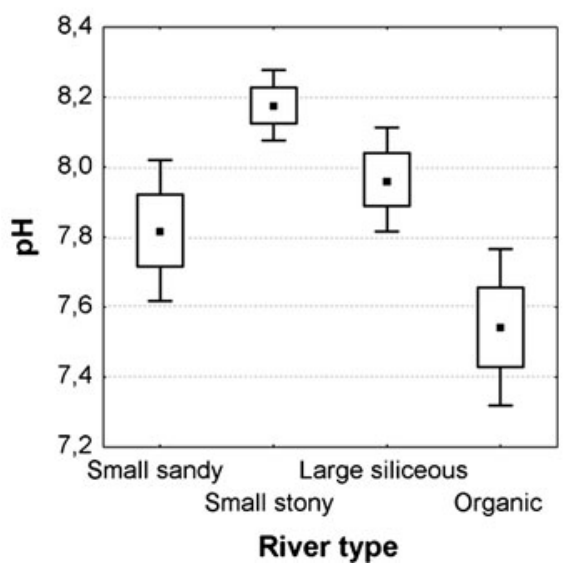

conductivity. These features enable treatment of the third component as an 'Eutrophication' gradient.

To investigate the relationship between environmental factors and macrophyte assemblages revealed by Twinspan analyses, CCA was performed (Fig. 4). PCA principal components were used as environmental variables. It was found that there are two dominant environmental variables explaining species variability. These are river size and land use, and they represent completely independent directions of variability as they are perpendicular to each other on the biplot. It was found that eutrophication axis is significantly shorter than other two, indicating a minor role of this factor for differentiating river vegetation. It was found that eutrophication was strongly negatively associated with land use. 
Table 5 Factor loadings of the first four principal components-result of the principal component analysis (PCA) after varimax rotation

\begin{tabular}{|c|c|c|c|}
\hline \multirow[t]{2}{*}{ Parameter } & \multicolumn{3}{|c|}{$\begin{array}{l}\text { Values of principal } \\
\text { components }\end{array}$} \\
\hline & 1 & 2 & 3 \\
\hline Catchment & 0.75 & 0.28 & 0.04 \\
\hline Arable $\%$ & 0.02 & 0.89 & 0.11 \\
\hline Grass $\%$ & 0.66 & 0.19 & -0.01 \\
\hline Forest $\%$ & -0.18 & -0.90 & -0.11 \\
\hline Wetland\% & 0.57 & 0.35 & 0.05 \\
\hline HQA & -0.62 & 0.11 & -0.13 \\
\hline HMS & 0.27 & 0.25 & -0.14 \\
\hline Alcal & -0.59 & 0.02 & -0.01 \\
\hline Cond & -0.51 & 0.06 & 0.52 \\
\hline $\mathrm{pH}$ & -0.40 & 0.56 & 0.00 \\
\hline Ortho_P & 0.00 & 0.23 & 0.87 \\
\hline Total_P & 0.06 & 0.05 & 0.89 \\
\hline Nitrate & 0.65 & -0.25 & 0.16 \\
\hline Ammonium & 0.31 & -0.44 & 0.57 \\
\hline Variance explained & 3.10 & 2.52 & 2.24 \\
\hline$\%$ of total variance explained & 22.2 & 18.1 & 16.8 \\
\hline
\end{tabular}

Full names of environmental variables are given in Table 3 (boldface loadings $>0.7$ )

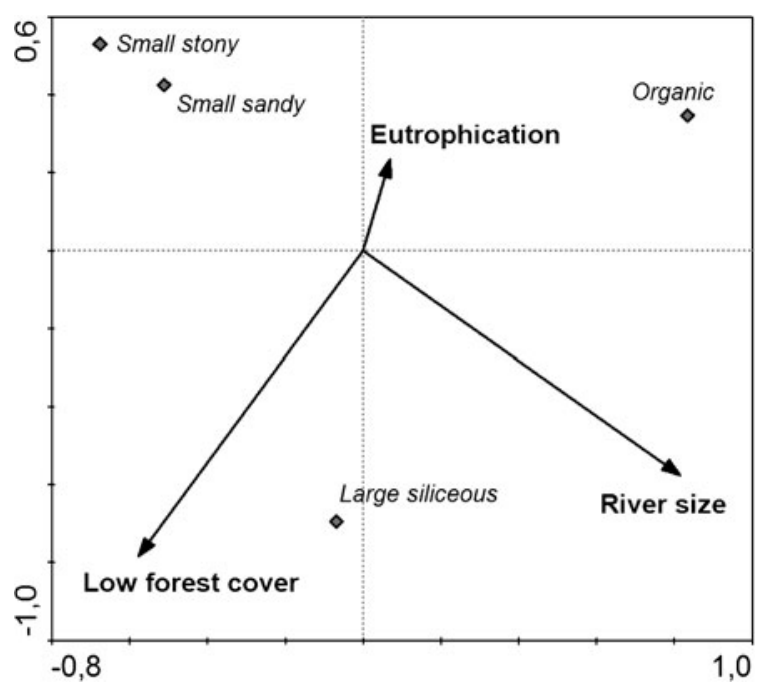

Fig. 4 CCA-ordination diagram of macrophyte species and environmental variables in lowland streams

The CCA analysis revealed that development of aquatic species in large rivers and organic streams is most strongly dependent on the land use gradient, but its reaction to this factor in each type of river is completely opposite. The botanical significance of these two river types also depends on the size of a river. This factor is the only one of the analysed variables which significantly influences development of species in both types of small rivers. There is no dominant environmental variable explaining species variability between two types of small rivers.

\section{Botanical diversification of river types}

Based on botanical surveys, a several macrophyte metrics were calculated. These were the numerical index MIR (Macrophyte Index for Rivers), five diversity metrics and presence of six growth forms. Analysis of variance showed that with the exception of MIR and domination $(C)$ indices are differentiated between river types (Table 6).

The post hoc tests comparisons of mean macrophyte metrics between river types were performed. It is graphically presented in Fig. 5. Species diversity defined by species richness (number of species), Shannon index as well as evenness, was highest for the organic river type. The smallest diversity was found in small siliceous rivers with sandy substrates. This pattern is caused by uneven cover of species rather than number of species-the species richness was very similar although the evenness and Shannon index values were very low in case of small sandy

Table 6 Analysis of variance of macrophyte metrics between river types

\begin{tabular}{lcc}
\hline Variable & $F$ distribution & $P$ value \\
\hline MIR & 1.61 & 0.204 \\
$N$ & 3.32 & $0.030^{*}$ \\
$H^{\prime}$ & 7.85 & $<0.001 * * *$ \\
$J$ & 7.90 & $<0.001 * * *$ \\
$D$ & 2.92 & $0.047 *$ \\
$C$ & 0.91 & 0.446 \\
Algae cover & 6.14 & $<0.001 * * *$ \\
Moss cover & 4.58 & $<0.001 * * *$ \\
Elodeids cover & 10.44 & $<0.001 * * *$ \\
Nympheids cover & 7.20 & $<0.001 * * *$ \\
Pleuston cover & 7.43 & $<0.001 * * *$ \\
Helophytes cover & 6.27 & $0.002^{* *}$ \\
Total cover & 7.52 & $<0.001 * * *$ \\
\hline
\end{tabular}

Full names of macrophyte indices are given in Table 1 df $=20 ; * P<0.05$; ** $P<0.01$; *** $P<0.001$ 
Fig. 5 Variability of macrophyte metrics among analysed river types. The plot indicates mean value, \pm standard error and $\pm 1.96 *$ standard error. The MIR index and five selected variables revealed as significantly differentiated between river types. Full names of metrics in Table 2
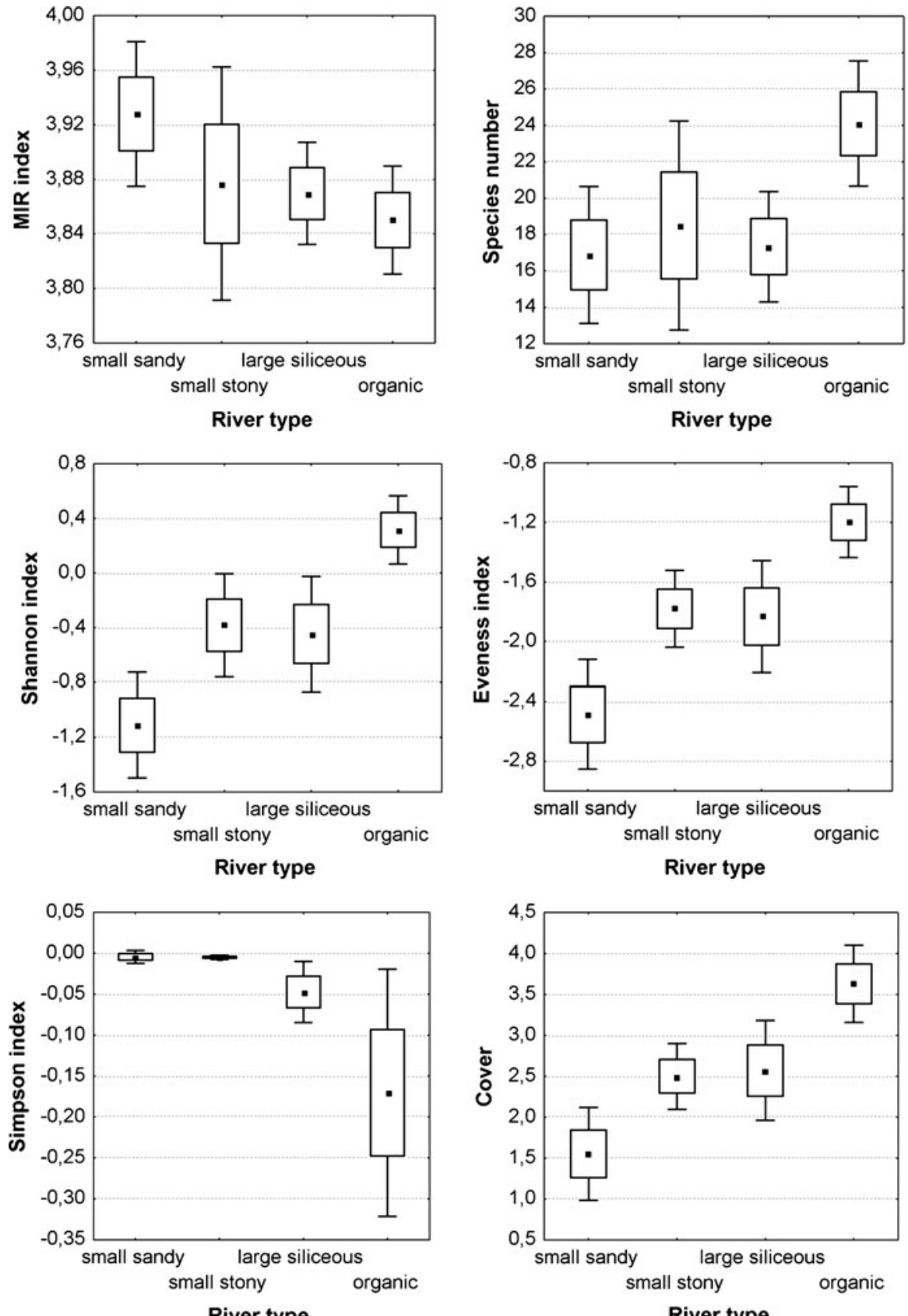

River type rivers. There was a high degree of overlap between the large rivers and small stony streams, i.e. most of calculated metrics were very similar in case of mean value as well as variance.

Analyses revealed that the presence of various growth forms of plants is differentiated between the four identified types of rivers (Fig. 6). It was found that both types of small rivers are overgrown mainly by emergent plants (helophytes). They represented $68.5 \%$ of all vegetation in case of sandy bottom streams and $58.9 \%$ in stony substrate streams. Mosses and liverworts (bryophytes) also play an important role in small streams. Stony rivers also had a high share of algae, which covered $25.6 \%$ of the vegetated area. Organic rivers were rich in nympheides $(28.4 \%)$ and pleustophytes (22.0\%). Large lowland rivers had 
Fig. 6 Percentage share of growth forms of aquatic plants in different macrophyte types of rivers

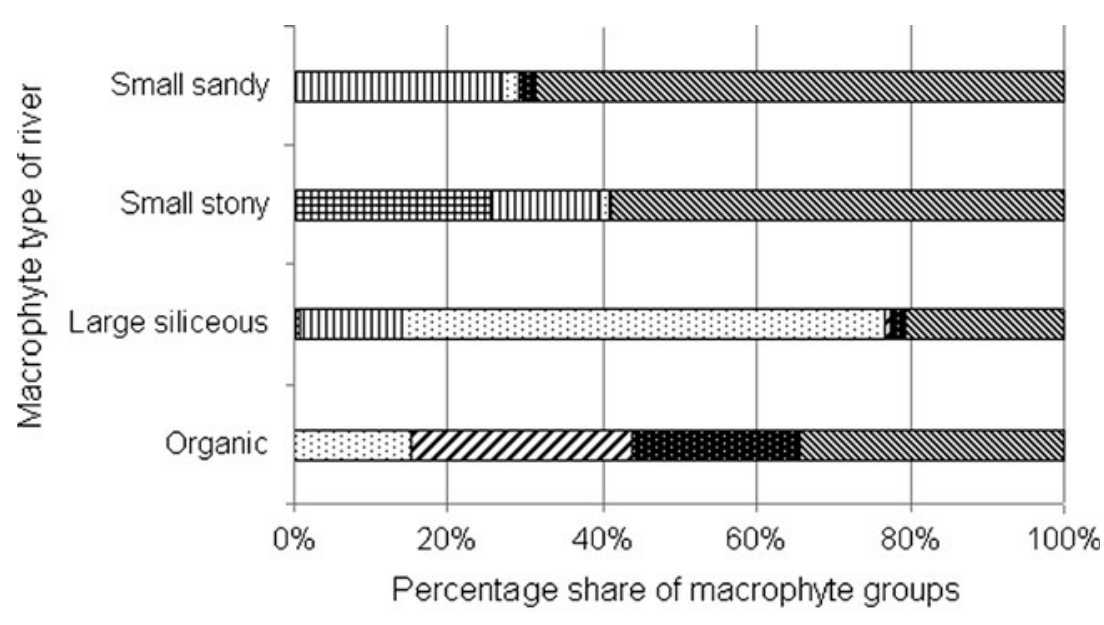

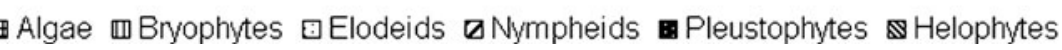

relatively large proportions of submerged plants (elodeides), reaching $62.7 \%$.

The relationship between aquatic plant species and macrophyte types of lowland rivers was revealed as a result of CCA analysis, which is presented graphically (Fig. 7). The percentage variance explained by the axes for the relationships between aquatic plants species and macrophyte types of rivers was first axis $49.0 \%$ and second axis $30.5 \%$. Large and medium siliceous rivers are preferred mainly by submerged species as: Fontinalis antipyretica, Mougeotia sp., Potamogeton crispus, P. pectinatus, Ranunculus fluitans, R. trichophyllus, Callitriche sp. and Butomus umbellatus. Organic rivers were characterised by such emergent species as: Calla palustris, Carex paniculata, C. rostrata, Cicuta virosa, Menyanthes trifoliata and Ranunculus lingua. Both types of small streams with sandy or gravel bed material were preferred by very similar species of plants, mainly bryophytes and liverworts (Chiloscyphus polyanthos, Conocephalum conicum, Cratoneuron filicinum, Hygroamblystegium tenax), but also algae species (Hildenbrandia rivularis) and vascular plants (Glyceria plicata).

\section{Discussion and conclusions}

Analysed dataset

The database of reference lowland rivers included 40 sites and is one of the largest ever analysed in case of macrophytes. For example, studies of Meilinger et al.
(2005) in Germany was based on only 19 reference sites which were utilised in development of river typology. A large macrophyte dataset was gathered as a result of European-wide project STAR, where 64 unimpacted sites were surveyed (Baattrup-Pedersen et al., 2006). Although, its typological variability was extremely high, that dataset combined lowland as well as mountain rivers. Moreover, it represented large geographical range (10 European countries including the Mediterranean zone and Scandinavia). A relatively large matrix of lowland data was analysed by Baattrup-Pedersen et al. (2008). It was a set of 63 reference sites from Northern Europe. Compared to our analysis, it was less homogenous, since the analysed dataset was compiled from various sources where several survey protocols and large number of independent groups of scientists were involved. The advantage of our dataset is its homogeneity in the result of strictly uniform field procedure. Moreover, all the surveys were undertaken by a group of surveyors regularly working together and also the process of intercalibration between them was conducted. The inter-personal variability might be an important source of analytical error in botanical studies (Staniszewski et al., 2006) but, due to conducted inter-surveyors intercalibration, this risk was very low in case of our analyses. It must be also underlined that the hydromorphological and hydrochemical datasets were also homogenously collected.

The criteria considered in reference site selection fulfil requirements of the WFD and are further explained in the REFCOND guidance (Wallin et al., 


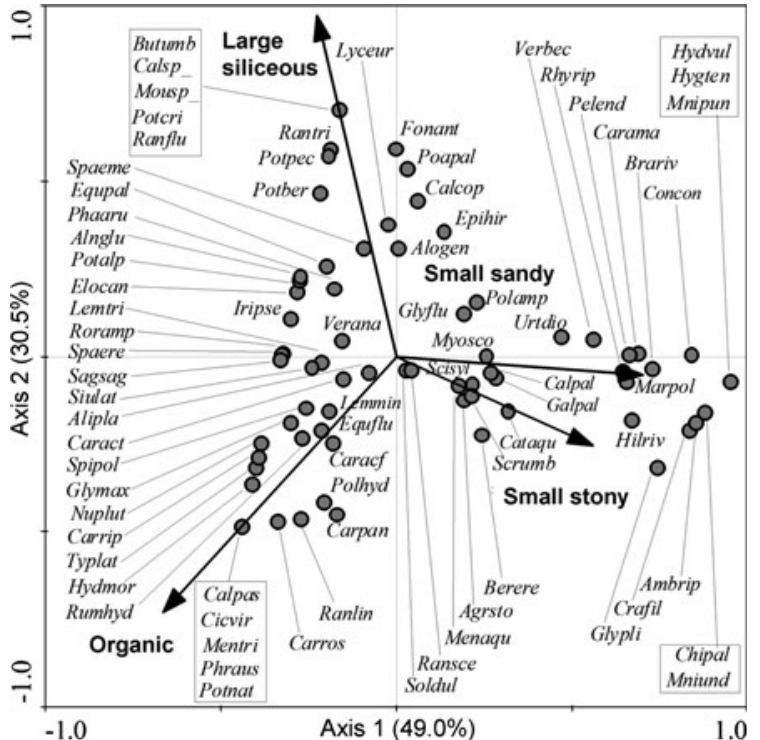

2003). The range of different elements used to define such conditions included a wide range of parameters related to catchment land use, hydromorphological features and water quality. The chosen criteria fulfil requirements outlined by other authors (Nijboer et al., 2004; Bald et al., 2005; Meilinger et al., 2005).

\section{Habitat condition and river types}

Habitat conditions of reference sites were described by numerous variables representing wide range of elements of environment. Ecological data included catchment area and watershed land use information, hydromorphological data and hydrochemical measurements. To uncover the environmental structure, PCA was performed. Derived PCA gradients proved to be significant in distinguishing different biological patterns. The size of a river was defined by a catchment area and several other associated features such as share of grasslands and wetlands (positively associated with the catchment area). Large lowland rivers are characterised by the presence of regularly flooded valleys, which are often covered by more or less hydrophilous vegetation. This complex factor has been identified as a very important determinant of macrophyte development by Dodkins et al. (2005), Szoszkiewicz (2004) in Great Britain and Jones et al. (2008) in Canada.

The second important factor identified as significant for river habitat was land use. The strongest
4Fig. 7 CCA-ordination diagram of macrophyte species and river types. Agrsto-Agrostis stolonifera, Alipla-Alisma plantago-aquatica, Alogen-Alopecurus geniculatus, Alnglu -Alnus glutinosa, Ambrip-Amblystegium riparium, Berere - Berula erecta, Brariv-Brachythecium rivulare, ButumbButomus umbellatus, Calpas-Calla palustris, Calcop-Callitriche cophocarpa, Calsp__Callitriche sp., Carama-Cardamine amara, Caract-Carex acuta, Caracf-Carex acutiformis, Carpan-Carex paniculata, Carrip-Carex riparia, Carros-Carex rostrata, Cataqu-Catabrosa aquatica, Chipal-Chiloscyphus pallescens, Cicvir-Cicuta virosa, Concon-Conocephalum conicum, Crafil-Cratoneuron filicinum, Elocan-Elodea canadensis, Epihir-Epilobium hirsutum, Equflu-Equisetum fluviatile, Equpal-Equisetum palustre, Fonant-Fontinalis antipyretica, Galpal-Galium palustre, Glyflu-Glyceria fluitans, Glymax-Glyceria maxima, Glipli - Glyceria plicata, Hilriv-Hildenbrandia rivularis, Hydmor-Hydrocharis morsus-ranae, Hydvul-Hydrocotyle vulgaris, Hygten-Hygroamblystegium tenax, Iripse-Iris pseudacorus, Lemmin-Lemna minor, Lemtri-Lemna trisulca, Marpol-Marchantia polymorpha, Menaqu-Mentha aquatica, Mentri-Menyanthes trifoliata, Mnipun-Mnium punctatum, Mniund-Mnium undulatum, Mousp__Mougeotia sp., Myosco-Myosotis scorpioides, Nuplut-Nuphar lutea, Pelend-Pellia endiviifolia, Phaaru-Phalaris arundinacea, Phraus-Phragmites australis, Poapal-Poa palustris, Polamp-Polygonum amphibium, Polhyd-Polygonum hydropiper, Potalp-Potamogeton alpinus, Potber-Potamogeton berchtoldii, Potcri-Potamogeton crispus, Potnat-Potamogeton natans, Potpec-Potamogeton pectinatus, RanfluRanunculus fluitans, Ranlin-Ranunculus lingua, RansceRanunculus sceleratus, Rantri-Ranunculus trichophyllus, Rhyrip—Rhynchostegium riparioides, Roramp—Rorippa amphibia, Rumhyd-Rumex hydrolapathum, Sagsag-Sagittaria sagittifolia, Scisyl-Scirpus sylvaticus, Scrumb-Scrophularia umbrosa, Siulat-Sium latifolium, Soldul-Solanum dulcamara, Spaeme-Sparganium emersum, Spaere-Sparganium erectum, Spipol -Spirodela polyrhiza, Typlat-Typha latifolia, Urtdio-Urtica dioica, Verana-Veronica anagallis-aquatica, Verbec-Veronica beccabunga

relation was observed in the ratio of forest to arable land area. Also some correlation between water $\mathrm{pH}$ and forestation-deforestation was found. The share of grasslands and wetlands was less important since these two categories appeared to be independently associated with large watercourses.

Several other physical and chemical parameters were also identified in the literature as strongly influencing river characteristics. The most important are total phosphorous and nitrate (Haury, 1996; Dodkins et al., 2005), several geographical and morphological variables such as type of substrate, altitude and slope (Dodkins et al., 2005; BaattrupPedersen et al., 2006). Trophic status appeared to be marginal in our studies, because we focused on 
lowland reference sites. The eutrophication influence (indicated by nitrate and phosphorous) was weak due to natural low amount of nutrients in the water. The other variables, such as altitude and slope, were not within the scope of analyses in the presented studies, because they were very homogenous in analysed lowland rivers.

\section{River typology}

Our studies showed a high degree of variability in macrophyte structure among investigated river types. In the result of Twinspan classification, assemblage patterns could be characterised independently from the existing abiotic typology. It has revealed four distinct macrophyte communities which turned out to fit with several criteria used for abiotic classification of rivers, although the differentiation between stony and sandy substrate was found only for the smallest rivers. Larger siliceous watercourses were identified as a homogenous cluster. Differences between small and large organic rivers were not detected.

Several similarities with the river typology system developed in Great Britain (Holmes, 1989) can be found. Holmes identified four groups (A-D) based on a classification of more than 1,500 British stream and river sites. Although, in contrary to presented surveys, he analysed impacted and unimpacted sites together. Large siliceous river type identified in this study is comparable to British 'River Community Type I' (RCT 1) in 'A' group. The main similarities are low mean altitude, shallow gradient and species composition represented by significant share of helophytes. The RCT 7 type identified by Holmes (Holmes, 1989) located in a 'C' group is comparable to small stony rivers distinguished in Polish typology. The RCT 4 type is not comparable to any type presented in this article, because it is defined by impoverished rivers, impacted by human activity. These kind of rivers were not included into Polish typology analysis, because they have been based only on reference rivers.

Holmes (1989) identified the lowland clay-dominated river type (RCT II). This type of rivers is only very rarely observed in Poland. Only in south-eastern Poland were a few sites identified. Because of the lack of reference sites of this type no further analyses for this kind of river were conducted.
River typology based on Twinspan classification was confirmed during further analyses. Each of revealed river types showed several statistically significant habitat features. Moreover, apart from Twinspan classification, other botanical indices proved significant differences between distinguished river types. Some similarities between presented river types and other European studies can be found. German typology studies of Meilinger et al. (2005) distinguished three types of lowland rivers. These are large lowland streams of northern Germany, mediumsized lowland rivers of northern Germany and fast flowing rivers and brooks of northern Germany. The first type can be compared with our large siliceous rivers. Also the third German type is quite similar to the Polish type: small stony rivers.

Analyses undertaken by Baattrup-Pedersen et al. (2006) on the international dataset were more general. Only one type of lowland stream reference community was identified (namely C6 group). Assemblages recognised in our studies can be regarded as subgroups of that community.

The comparison of lowland communities identified later by Baattrup-Pedersen et al. (2008) is not simple. The database analysed in our studies was abiotically more diverse, containing a variety of substrates (organic, stony and sandy) whereas the international dataset of Baattrup-Pedersen et al. (2008) was dominated by sandy rivers. We also managed to collect data from several high quality large rivers, therefore, our dataset was more variable in terms of river discharge and we were able to reveal the significance of large river macrophyte communities.

The observed diversity of abiotic conditions provided a strong basis for identifying new lowland river types. We can assert that both plant species and abiotic conditions, which we have discovered in Poland, are common for many countries in Europe.

\section{Botanical reaction to habitat conditions}

The list of species found in reference conditions in Poland is long. Only several of them were commonly identified as typical for reference conditions in Europe. Regarding Germany (Schaumburg et al., 2004), the list of bryophytes is much longer compared to our findings although our studies were limited to lowland sites only, where mosses and 
liverworts are less frequent. The systems for lowland rivers cannot be limited to bryophytes.

We have found that numerous species of vascular macrophytes were present in all of the investigated river types and many of them should be regarded as potential indicators of reference conditions for running water ecosystems. Similar observations were conducted by Pott \& Remy (2000). On the other hand, our observations of lowland rivers with clay substrates or heavily shaded rivers suggest that they are naturally deficient in vascular macrophytes. Also, Pott \& Remy (2000) disputed the presumption that the absence of vascular plants is a sign of degradation for certain sites. Several macrophyte systems widely used in Europe also involve vascular plants as indicators of high quality sites, for example IBMR (Haury et al., 2006) and MTR (Holmes et al., 1999).

The share of algae is very limited in reference streams. Hildenbrandia rivularis is the only species which can be indicative and it is quite common in European streams (e.g. Holmes et al., 1999; Haury et al., 2006). The presence of other algae species is not unusual although their cover is very low in the pristine sections.

Acknowledgments Lucy Baker and Lucy Taylor improved the manuscript through helpful comments. Barbara Andrzejewska and Marta Szwabińska helped with the analytical work. Their assistance is gratefully acknowledged. This research has been supported by a Ministry of Science and Higher Education (contract 2 PO4G 136 29) and National Centre for Research and Development (contract R14 0015 04).

Open Access This article is distributed under the terms of the Creative Commons Attribution Noncommercial License which permits any noncommercial use, distribution, and reproduction in any medium, provided the original author(s) and source are credited.

\section{References}

Baattrup-Pedersen, A., K. Szoszkiewicz, R. Nijboer, M. O'Hare \& T. Ferreira, 2006. Macrophyte communities in unimpacted European streams: variability in assemblage patterns, abundance and diversity. Hydrobiologia 566: 179-196.

Baattrup-Pedersen, A., G. Springe, T. Riis, S. E. Larsen, K. Sand-Jensen \& L. M. Kjellerup Larsen, 2008. The search for reference conditions for stream vegetation in northern Europe. Freshwater Biology 53: 1890-1901.

Bald, J., A. Borja, I. Muxika, J. Franco \& V. Valencia, 2005. Assessing reference conditions and physico-chemical status according to the European Water Framework Directive: a case-study from the Basque Country (Northern Spain). Marine Pollution Bulletin 50: 1508-1522.

Blachuta, J., K. Czoch, K. Kulesza \& J. Picinska-Faltynowicz, 2005. Typologia rzek i strumieni Polski. Conference Proceedings: Wdrażanie Ramowej Dyrektywy Wodnej; Ocena stanu ekologicznego wód w Polsce. University of Łódź, Łódź: 5-7.

Dawson, F. H., 2002. Guidance for the field assessment of macrophytes of rivers within the STAR Project, http:// www.eu-star.at/frameset.htm.

Dodkins, I., B. Rippey \& P. Hale, 2005. An application of canonical correspondence analysis for developing ecological quality assessment metrics for river macrophytes. Freshwater Biology 50: 891-904.

Environment Agency, 2003. River Habitat Survey in Britain and Ireland Field Survey Guidance Manual 2003 Version. Environment Agency of England \& Wales, Warrington: $1-136$.

European Commission, 2000. Directive 2000/60/EC of the European Parliament and of the Council - Establishing a Framework for Community Action in the Field of Water Policy, Brussels, Belgium.

Ferreira, M. T., A. Albuquerque, F. C. Aguiar \& N. Sidorkewicz, 2002. Assessing reference sites and ecological quality of river plant assemblages from an Iberian basin using a multivariate approach. Archiv für Hydrobiologie 155: 121-145.

Haury, J., 1996. Assessing functional typology involving water quality, physical features and macrophytes in a Normandy river. Hydrobiologia 340: 43-49.

Haury, J., M.-C. Peltre, M. Trémolières, J. Barbe, G. Thiébaut, I. Bernez, H. Daniel, P. Chatenet, G. Haan-Archipof, S. Muller, A. Dutartre, C. Laplace-Treyture, A. Cazaubon \& E. Lambert-Servien, 2006. A new method to assess water trophy and organic pollution - the Macrophytes Biological Index for Rivers (IBMR): its application to different types of river and pollution. Hydrobiologia 570: 153-158.

Hill, M. O., 1979. TWINSPAN - a Fortran program for arranging multivariate data in an ordered two-way table by classification of the individuals and attributes. Cornell University, Ithaca.

Holmes, N. T. H., 1989. British rivers - a working classification. British Wildlife 1: 20-36.

Holmes, N. T. H., J. R. Newman, S. Chadd, K. J. Rouen, L. Saint \& F. H. Dawson, 1999. Mean trophic rank: a users manual. R\&D Technical Report E38, Environment Agency of England \& Wales, Bristol: 1-134.

Jones, N., G. Scrimgeour \& W. Tonn, 2008. Assessing the effectiveness of a constructed arctic stream using multiple biological attributes. Environmental Management 42: 1064-1076.

McNaughton, S. J., 1967. Relationships among functional properties of Californian Grasslands. Nature 216: 168-169.

Meilinger, P., S. Schneider \& A. Melzer, 2005. The Reference Index method for the macrophyte-based assessment of rivers - a contribution to the implementation of the European Water Framework Directive in Germany. International Review of Hydrobiologia 90: 322-342.

Nijboer, R. C., R. K. Johnson, P. F. M. Verdonschot, M. Sommerhäuser \& A. Buffagni, 2004. Establishing reference conditions for European streams. Hydrobiologia 516: 91-105. 
Passauer, B., P. Meilinger, A. Melzer \& S. Schneider, 2002. Does the structural quality of running waters affect the occurrence of macrophytes? Acta Hydrochimica et Hydrobiologica 30: 197-206.

Pielou, E. C., 1966. The measurement of diversity in different types of biological collections. Journal of Theoretical Biology 13: 131-144.

Pott, R. \& D. Remy, 2000. Gewässer des Binnenlandes. Eugen Ulmer Verlag, Stuttgart: 1-255.

Raven, P. J., N. T. H. Holmes, F. H. Dawson, P. J. A. Fox, M. Everard, I. R. Fozzard \& K. J. Rouen, 1998. River habitat quality the physical character of rivers and streams in the UK and Isle of Man. Environment Agency, Stirling. Environment and Heritage Service, Belfast: 1-96.

Raven, P. J., N. Holmes, P. Scarlett, K. Szoszkiewicz, A. Lawniczak \& H. Dawson, 2008. River habitat and macrophyte surveys in Poland. Results from 2003 and 2007. Environment Agency, Bristol: 1-29.

Schaumburg, J., C. Schranz, J. Foerster, A. Gutowski, G. Hofmann, P. Meilinger, S. Schneider \& U. Schmedtje, 2004. Ecological classification of macrophytes and phytobenthos for rivers in Germany according to the Water Framework Directive. Limnologica 34: 283-301.

Schneider, S., T. Krumpholz \& A. Melzer, 2000. Trophäeindikation in Fliessgewässern mit Hilfe des TIM (TrophäeIndex Macrophyten) - Erprobung eines neu entwickelten Index im Inniger Bach. Acta Hydrochimica et Hydrobiologica 28: 241-249.

Shannon, C. E. \& W. Weaver, 1949. The Mathematical Theory of Communication. University of Illinois Press, Urbana: $1-117$.

Simpson, E. H., 1949. Measurement of diversity. Nature 163: 688.

Staniszewski, R., K. Szoszkiewicz, J. Zbierska, J. Leśny, S. Jusik \& R. Clark, 2006. Assessment of sources of uncertainty in macrophyte surveys and the consequences for river classification. Hydrobiologia 566: 235-246.

StatSoft, Inc., 2008. STATISTICA (data analysis software system), version 8, www.statsoft.com.

Svendsen, L. \& A. Rebsdorf, 1994. Kvalitetssikring af Overvågningsdata. Retningslinier for Kvalitetssikring af Ferskvandskemiske Data i Vandmiljøplanenes Overvågningsprogram (Quality Assurance of Monitoring Data). Teknisk Anvisning fra DMU vol. 7: 1-87.

Szoszkiewicz, K., 2004. Vegetation as an indicator of trophic status of running waters based on rivers of Great Britain and northern Ireland. Roczniki Akademii Rolniczej w Poznaniu. Rozprawy Naukowe 349: 1-116.

Szoszkiewicz, K., J. Zbierska, S. Jusik \& T. Zgola, 2010. Metodyka badań terenowych makrofitów na potrzeby rutynowego monitoringu rzek [Macrophyte survey manual for the purpose of river monitoring]. Bogucki Wydawnictwo Naukowe, Poznan.

Ter Braak, C. J. F. \& I. C. Prentice, 1988. A theory of gradient analysis. Advances in Ecological Research 18: 271-317.

Tremp, H. \& A. Kohler, 1995. The usefulness of macrophyte monitoring-systems, exemplified on eutrophication and acidification of running waters. Acta Botanica Gallica 142: 541-550.

Van De Weyer, K., 2003. Kartieranleitung zur Erfassung und Bewertung der aquatischen Makrophyten der Fließgewässer in NRW gemäß den Vorgaben der EU-Wasser-Rahmenrichtlinie. Landesumweltamt Nordrhein-Westfalen (LUA), Merkblätter 39: 1-60.

Wallin, M., T. Wiederholm \& R. Johnson, 2003. Guidance on establishing reference condition and ecological status class boundaries for inland surface waters. Final Report to the European Commission from CIS Working Group 2.3. REFCOND. 